Jurnal Keperawatan Silampari

Volume 2, Nomor 1, Desember 2018

e-ISSN: 2581-1975

p-ISSN: 2597-7482

DOI: https://doi.org/10.31539/jks.v2i1.314

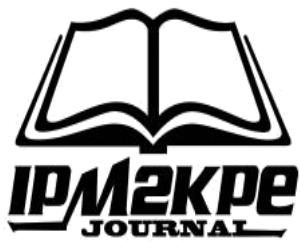

\title{
PENGARUH PAPARAN RADIASI GELOMBANG ELEKTROMAGNETIK WI-FI 4G TERHADAP BERAT EPIDIDIMIS DAN MORFOLOGI SPERMA TIKUS JANTAN WISTAR
}

\author{
Meily Nirnasari \\ Program Studi Ners, STIKES Hang Tuah Tanjung Pinang \\ Meilynirnasari82@gmail.Com
}

\begin{abstract}
ABSTRAK
Tujuan penelitian ini adalah untuk mengetahui bagaimana pengaruh paparan radiasi gelombang elektromagnetik Wi-Fi4G terhadap berat testis epidedemis dan kualitas sperma pada tikus jantan Wistar (Rattus Norvegicus). Metode penelitian yang digunakan dalam penelitian adalah metode penelitian eksperimental dengan postest control group design. Hasil analisis data dilakukan dengan uji One Way Anova, setelah diberi paparan radiasi gelombang elektromagnetik $W i-F i 4 G$ menunjukkan rerata yang berbeda secara bermakna, menurunkan berat epididimis, morfologi sperma nilai ( $\mathrm{p}=$ $0,000)$ dengan nilai alpha $0,05(\mathrm{p}<\alpha)$ di banding dengan kelompok kontrol. Simpulan, paparan radiasi gelombang elektromagnetik Wi-Fi4G dapat menurunkan berat epididimis dan morfologi sperma pada tikus wistar jantan.
\end{abstract}

Kata Kunci: Epididimis, Morfologi Sperma, Wi-Fi $4 G$

\begin{abstract}
The purpose of this study was to determine how the effect of Wi-Fi4G electromagnetic radiation exposure on epidedemic testis weight and sperm quality in Wistar male rats (Rattus Norvegicus). The research method used in the study is an experimental research method with posttest control group design. The results of data analysis were performed with the One Way Anova test, after being given exposure to $4 G$ Wi-Fi electromagnetic radiation radiation showed significantly different mean, reduced epididymal weight, sperm morphology value $(p=0,000)$ with alpha value of $0.05(p<\alpha)$ compared with the control group. Conclusion, exposure to Wi-Fi4G electromagnetic wave radiation can reduce the epididymic weight and sperm morphology in male wistar rats.
\end{abstract}

Keywords: Epididymis, Sperm Morphology, 4G Wi-Fi 


\section{PENDAHULUAN}

Infertilitas adalah keadaan yang ditandai dengan tidak terjadinya kehamilan pada pasangan individu yang secara aktif melakukan hubungan seksual secara teratur tanpa menggunakan pengaman selama satu tahun. Infertilitas dapat bersifat primer dan sekunder. Pada studi epidemiologi batasan infertilitas adalah dua tahun (Roupa et al, 2009).

Infertilitas merupakan ketidakmampuan untuk mengandung sampai melahirkan bayi hidup setelah satu tahun melakukan hubungan seksual yang teratur dan tidak menggunakan alat kontrasepsi apapun setelah memutuskan untuk mempunyai anak. Jenis infertilitas terbagi menjadi dua, yakni infertilitas primer dan infertilitas sekunder, penyebab infertilitas pria antara lain kelainan anatomi, gangguan endokrin dan disfungsi seksual dan gangguan perkembangan proses spermatogenesis. Spermatogenesis abnormal dapat terjadi akibat penyakit infeksi, kelainan kromosom, terpajan bahan kimia, radiasi atau varikokel, kegagalan pasangan suami istri (pasutri) dalam memperoleh keturunan, disebabkan oleh masalah pada pria dan atau wanita. 40 persen kesulitan mempunyai anak terdapat pada wanita, 40 persen pada pria, dan 30 persen pada keduanya (Saraswati.A, 2015).

Seiring dengan perkembangan teknologi selama beberapa dekade terakhir ini Terdapat 70 juta pasangan usia reproduksi di dunia mengalami infertilitas penurunan kesuburan pria karena faktor lingkungan tertentu seperti radiasi gelombang elektromagnetik wi-fi (Conrado.A. et al, 2012).

Pada studi epidimiologi menunjukan insiden infertilitas primer di wilayah india pada 20 tahun terakhir mencapai $62 \%$ sedangkan infertilitas sekunder mencapai $38 \%$, Terdapat perbedaan angka prevalansi tertinggi berada di negara Prancis mencapai 59\%, di Inggris dan India berkisar 26-32\% sedangkan di negara-negara berkembang seperti Afrika Selatan, Indonesia dan Finlandia mencapai 36\% (Samal et al, 2012).

Medan elektromagnetik merupakan medan listrik dan medan magnet yang dapat ditimbulkan secara alamiah oleh alam ataupun secara buatan oleh peralatan listrik buatan manusia lingkungan kehidupan di bumi tidak dapat dipisahkan dari keberadaan medan elektromagnetik alamiah yang berkekuatan sekitar 0,1 sampai $0,5 \mathrm{kV} / \mathrm{m}$ dan keberadaan medan magnet yang berkekuatan sekitar 40 sampai $70 \mathrm{mT}$ (Swamardika Alit, 2009).

Penggunaan perangkat listrik menjadi bagian yang esensial dari kehidupan manusia dan merupakan elemen yang intergral kehidupan modern. Manusia tidak hanya terpapar oleh sumber-sumber medan elektromagnetik alami tetapi juga oleh sumber medan elektomagnetik buatan dengan frekuensi yang bervariasi seperti perangkat listrik rumah tangga, alat komunikasi elektronik ataupun alat-alat industri. Perangkat listrik yang kita gunakan sehari-hari menghasilkan Extremely Low Frequency-Electromagnetic Field (ELF-EMF) yaitu suatu jenis radiasi non-ion yang di laporkan dapat menimbulkan efek buruk pada kesehatan manusia antara lain kesuburan (Foster, KR et al, 2013).

Infertilitasi pria selama beberapa dekade terakhir ini terkait dengan paparan langsung atau tidak langsung dengan faktor lingkungan tertentu seperti gelombang frekuensi radio elektromagnetik yaitu wi-fi. Wi-fi adalah sebuah teknologi terkenal yang memanfaatkan peralatan elektronik untuk bertukar data secara nirkabel (menggunakan gelombang radio, wireless) melalui sebuah jaringan komputer, termasuk koneksi Internet berkecepatan tinggi, wi-fi saat ini sudah banyak sekali digunakan Manusia sekarang mentransmisikan dan menggunakan listrik dengan cara yang meningkat pesat sebagai komponen penting kehidupan modern. Kehidupan modern yang terhubung 
dengan listrik ini telah menyebabkan meningkatnya eksposur yang cepat terhadap berbagai tingkat elektromagnetik, radiasi elektromagnetik adalah salah satu toxicants lingkungan yang mampu mengorbankan kesuburan pria dengan menginduksi keadaan stres oksidatif dalam testis. Akibatnya ada kebutuhan mendesak untuk mengidentifikasi antioksidan yang dapat melengkapi srategi antioksida jaringan sendiri untuk melindungi testis dari serangan ROS. Dalam vitro studi oleh avendano et.al di fokuskan pada efek radiasi wi-fi pada pengurangan motilitas dan DNA fragmentasi spermatozoa manusia. Hal ini di yakini bahwa paparan EMR dapat meningkatkan produksi spesies Oksigeal Reaktif (ROS) peningkatan tingkat peroksidasi lipid selain penurunan enzim antioksidan, dan mempercepar apoptosis yang pada akhirnya mempengaruhi kualitas sperma (Conrado,A et al,2012).

Tingkat fertilitas atau kesuburan dipengaruhi oleh kwantitas dan kualitas sperma, kualitas sperma sangat penting bagi individu untuk mempertahankan generasinya, kualitas sperma meliputi beberapa aspek antara lain motilitas atau daya gerak, morfologi, dan viabilitas atau daya tahan (Soehadi, Arsyad, 1983 dalam Ni made, Ni gusti, 2010).

Proses spermatogenesis terjadi di tubulus seminiferus testis. Dimana didalamnya terdapat sel-sel induk spermatozoa atau spermatogonium, sel sertoli yang berfungsi memberi makan spermatozoa juga sel leydig yang terdapat pada jaringan interstitial yang berfungsi menghasilkan testosteron. Adanya gangguan pada organ reproduksi ini akibat radiasi gelombang elektromagnetik secara tidak langsung akan mempengaruhi proses spermatogenesis (Guyton, Hall, 2008).

Testis merupakan organ reproduksi pria yang berfungsi untuk sintesis hormon testoteron dan tempat berlangsung proses spermatogenesis, selain kualitas sperma berat testis juga menunjukkan kesuburan atau fertilitas jantan, semakin besar ukuran testis akan diikuti dengan semakin banyak sel spermatozoa. Hal ini berarti akan semakin banyak spermatozoa yang akan diproduksi begitu juga dengan sel-sel pembentuk hormon (sel leydig) dalam testis sehingga kemampuan produksi testosteron juga akan tinggi (Guyton, Hall, 2008).

Paparan radiasi gelombang elektromagnetik wi-fi dapat menyebabkan kerusakan pada testis sehingga mengakibatkan sintesis hormon testoteron dan spermatogenesis terganggu. Kerusakan pada testis sering terjadi, karena pada pria letak testis kurang terlindungi dibandingkan dengan letak ovarium pada wanita yang lebih terlindungi sehingga testis lebih mudah terpapar pancaran peralatan Wireless-Fidelity (Wi-Fi)., sesuai dengan penelitian Saygin. M. et al (2014) gelombang wi-fi akan menghasilkan panas mempengaruhi apoptosis dan sel leydig jaringan testis pada tikus, sedangkan penelitian pada manusia menunjukan bahwa gelombang elektromagnetik wi-fi akan berpengaruh terhadap motilitas dan morfologi sperma manusia yang akan mengakibatkan infertilitas (Gilbert, Amuda \& Oni, 2011).

Wi-fi dapat mengakibatkan peningkatan stres oksidatif Reactive Oxygen Species (ROS) merusak sperma dan kelebihan produksi radikal bebas atau oksigen yang reaktif ROS telah diketahui sebagai salah satu penyebab infertilitas, radiasi gelombang elektromagnetik wi-fi pancaran radiasi akan berpengaruh terhadap penurunan jumlah sperma dan motilitas sperma (Soleimani et al, 2015).

Studi Penelitian mengatakan bahwa radiasi medan elektromagnetik wi-fi pada tikus akan menyebabkan peningkatan produksi Reactive Oxygen Species (ROS), seperti Malondialdehyde (MDA), penurunan aktivitas antioksidan, meningkatkan kadar peroksidasi lipid dan penurunan jumlah sperma, berat vesikula seminalis, jumlah sel 
apoptosis positif, terganggunya produksi testesteron serta terjadi peningkatan aktifitas caspase-3 pada tubulus seminiferus (Shokri et al, 2014).

Pada studi penelitian Halil. I et al, (2012) menunjukan tikus yang terkena paparan sumber gelombang elektromagnetik wi-fi 24 jam sehari selama 20 minggu mengakibatkan stress oksidatif diandai dengan penurunan kadar katalase dan peroksidasi glutathione lipid, serta dapat mempengaruhi keadaan membran plasma sel sperma, merusak struktur DNA serta mempercepat proses apoptosis yang mengakibatkan penurunan kualitas sperma. Sedangkan pada penelitian pada manusia paparan laptop terhubung internet nirkabel wi-fi menunjukan penurunan motilitas sperma dan peningkatan fragmentasi DNA sperma pada manusia (Canrado et al, 2012).

Penggunaan benda-benda yang mengandung gelombang elektromagnetik di zaman teknologi sekarang sudah menjadi gaya hidup dan sudah menjadi kebutuhan sehari-hari sebagai penunjang keberhasilan dalam beraktivitas, padahal gelombang elektromagnetik dapat merusak keshatan tubuh manusia terutam organ reproduksi jika digunakan tidak tepat dan berlebihan. Penelitian ini bertujuan untuk mengetahui bagaimana pengaruh paparan radiasi gelombang elektromagnetik wi-fi 4G terhadap berat epididimis dan morfologi sperma pada tikus putih jantan wistar (rattus norvegicus).

\section{METODE PENELITIAN}

\section{Jenis Penelitian}

Penelitian ini merupakan penelitian eksperimental di Laboratorium dengan menggunakan hewan percobaan tikus jantan wistar. Rancangan penelitian yang digunakan untuk pengelompokan dan pemberian perlakuan terhadap hewan uji adalah Rancangan Acak Lengkap.Sejumlah individu yang homogen dialokasikan secara random ke dalam kelompok secara lengkap.Kelompok perlakuan dalam eksperimen ini adalah kelompok tikus yang diberi paparkan radiasi Wi-Fi 4G.dengan menggunakan rancangan penelitian post-test only control group design.

\section{Waktu dan Tempat Penelitian}

Waktu penelitian dimulai bulan Desember 2017 s/d Maret 2018. Lokasi pemeliharaan dan perlakuan pada tikus adalah di Animal House di Fakultas Kedokteran Universitas Sriwijaya, sedangkan pembedahan, penghitungan kualitas sperma dan penimbangan berat tetis, epididimis di laboratorium bagian Biologi Kedokteran Universitas Sriwijaya.

\section{Populasi dan Sampel Penelitian}

Penelitian ini menggunakan populasi tikus putih jantan wistar, sampel penelitian sebanyak 28 ekor usia 60 hari, dengan berat badan 210-230 gram yang diperoleh dari IPB Institusi Teknologi Bogor yang sudah bersertefikasi. Sampel yang dimasukkan kedalam penelitian ini adlah, tikus jantan sehat, usia tikus 60 hariBerat badan rata-rata 210-230 gram, sedangkan tikus yang telah pernah digunakan dalam penelitian sebelumnya dan tikus mati selama pelaksanaan eksperimen tidak dimasukkan kedalam penelitian. 


\section{Besar Sampel Penelitian}

Penelitian ini menggunakan populasi tikus putih jantan wistar sebanyak 28 ekor, dengan berat badan 210-230 gram. Jumlah sampel adalah 24 ekor tikus, 4 kelompok dan untuk menjaga agar tingkat representatifnya tinggi apabila terjadi drop out, maka ditambahkan $10 \%$ dari perhitungan besar sampel, jadi sampel yang disiapkan berjumlah 28 ekor tikus.

\section{Cara Pengambilan Sampel Penelitian}

Tehnik penentuan sampel dilakukan dengan cara sebagai berikut:

Dari populasi tikus putih jantan Wistar diadakan pemilihan sampel berdasarkan kriteria inklusi. Dari jumlah sampel yang telah memenuhi syarat diambil secara random untuk mendapatkan jumlah sampel.

Sampel yang telah dipilih kemudian dibagi menjadi 2 kelompok secara random yaitu kelompok kontrol dan kelompok perlakuan, dari kelompok perlakuaan di bagi 3 kelompok, kelompok perlakuan 1 diberi paparan radiasi gelombang elektromagnetik wifi 4G pada tikus jantan wistar 8 jam per hari selama 48 hari, kelompok perlakuaan 2 diberi paparan radiasi gelombang elektromagnetik wi-fi $4 \mathrm{G}$ pada tikus jantan wistar 16 jam per hari selama 48 hari dan kelompok perlakuan 3 diberi diberi paparan radiasi gelombang elektromagnetik wi-fi $4 \mathrm{G}$ pada tikus jantan wistar 24 jam per hari selama 48 hari.

\section{Prosedur Penelitiaan}

Aklimatisasi tikus selama 7 hari sebelum perlakuan (tikus yang sudah bersertefikasi). Penimbangan berat badan tikus, dipilih yang sehat. Tikus dikelompokan dikandangkan dan setiap kandang berisi tikus sebanyak 6 ekor dan diberi makan makanan standar setiap hari selama 48 hari. Didalam setiap kandang diberi perangkat menggunakan perangkap modem wi-fi M3Y Long Term Evolution (LTE) Cat4 dari smartfren wi-fi 4G. yaitu andromak, Pengelompokan hewan uji dibagi 4 kelompok yaitu: a) Kelompok control P0 (tanpa paparan radiasi gelombang elektromagnetik wi-fi 4G pada tikus jantan wistar tidak diberikan perlakuan selama 48 hari). b) Kelompok perlakuan P1 (diberi paparan radiasi gelombang Wi-Fi 4G pada tikus putih jantan wistar 8 jam per hari selama 48 Hari). c) Kelompok perlakuan P2 (diberi paparan radiasi gelombang elektromagnetik wi-fi $4 \mathrm{G}$ pada tikus putih jantan Wistar 16 jam per hari selama 48 Hari). d) Kelompok perlakuan P3 (diberi paparan radiasi gelombang elektromagnetik wi-fi $4 \mathrm{G}$ pada tikus putih jantan wistar 24 jam per hari selama 48 Hari).

Pada hari ke 49 tikus-tikus dikorbankan dengan cara memasukan tikus kedalam wadah bertutup yang telah di beri kapas yang mengndung crolofom selama 5 menit hingga hilang kesadarannya, jika sudah kehilangan kesadaran tikus dikeluarkan dilakukan pembedahan pada tikus dengan membuka dinding perut, sehingga nampak testis dan epidedemis, bagian epidedemis diambil untuk ditimbang. Cauda epididimis yang telah dipisahkan diletakkan dalam cawan petri yang telah berisi $1 \mathrm{ml} \mathrm{NaCl} \mathrm{0,9 \%}$. Cauda epidedemis dan dipepeting agar tersuspensi dengan $\mathrm{NaCl} 0,9 \%$ sehingga terbentuk suspensi spermatozoa. Suspensi spermatozoa yang telah dibuat dapat digunakan untuk, penilaian morfologi.

Melakukan Perhitungan berat organ epididimis dilakukan dengan membuka kulit tubuh didaerah perut dengan posisi telentang. Kemudian organ epididimis diambil dengan cara memisahkan testis dan epididimis lalu dibersihkan dari jaringan ikat serta lemak. Setelah itu epididimis ditimbang dengan timbangan elektronik. 
Pengamatan morfologi spermazoa sperma diamati dari sediaan hapusan. Sediaan hapusan dibuat dari kaca objek suspensi spermatozoa diteteskan di atas gelas objek, dibuat preparat hapus dan dikeringkan di udara, Sediaan hapus difiksasi dengan metanol selama 3-5 menit, kemudian diwarnai dengan giemsa 3\% selama 30 menit, preparat dicuci dengan akuades dan dikeringkan pada suhu kamar, Pengamatan dilakukan dibawah mikroskop cahaya dengan pembesaran 400 kali pembesaran sampai 4 lapangan pandang terhadap 200 sperma dan hasilnya dinyatakan dalam persen. Pengamatan dilakukan pada sperma yang setelah dilakukan pengamatan $400 \mathrm{x}$ dengan 4 lapangan pandang, dengan melihat jenis morfologi sperma menurut (WHO, 2010).

Sperma normal mempunyai panjang dan lebar dengan batas teratur. Bagian kepala berkait berbentuk bulan sabit dan bagian ekor panjang tidak mengulung. Sperma abnormal, meliputi sperma makro: mempunyai ukuran kepala lebih besar dari pada normal, sperma mikro: mempunyai ukuran kepala yang lebih kecil dari pada normal, sperma double hand: mempunyai kepala dua dengan bentuk dan ukuran bervariasi, sperma amorf: mempunyai bentuk kepala yang aneh sehingga tidak dapat di golongkan kedalam sati kategori.

Pada bagian leher dan tengah sperm: sperma defek: sperma yang bagian tengahnya membelit atau patah, sperma loose head: sperma tanpa kepala. Sementara pada bagian ekor: sperma koil: mempunyai kelainan pada bagian ekor berupa bagia ekor membelit, sperma double tail: sperma dengan ekor ganda. persentase morfologi spermamengalami kelainan pada kepala, leher, dan ekor lalu dipersentasekan dengan rumus persentase dibawah ini:

\begin{tabular}{|lll|}
\hline \% Morfologi : & Jumlah spermatozoa abnormal & X $100 \%$ \\
\cline { 2 - 3 } & Total sperma yang diamati & \\
\hline
\end{tabular}

Hasil pemeriksaan terhadap subjek akan di jadikan data. Data tersebut sematamata akan digunakan sebagai bahan penelitiaan yang hasil penelitiaannya dapat dijadikan informasi yang berguna bagi masyarakat dan peneliti yang akan melakukan penelitiaan lebih lanjut. Data pada penelitian ini diolah dengan Analisis data menggunakan uji One Way Anova dan uji lanjut Duncan. Penelitian ini layak etik dari Komisi Etik Penelitian Kesehatan Rumah Sakit Umum Pusat Mohamad Hoesin dan Fakultas Kedokteran Universitas Sriwijaya Palembang.

\section{Analisis Kelayakan Etik}

Penelitian ini disusun berdasarkan telaah penelitian sebelumnya maupun kajian pustaka yang mendukung penelitian dan telah mempunyai landasan ilmiah yang kuat, sehingga dapat memberikan hasil yang sesuai dengan tujuan dan bermanfaat bagi peneliti dan masyarakat pada umumnya. Penggunaan hewan dalam penelitian ini telah sesuai dengan aturan etika penelitian yang diatur dalam deklarasi helsinski dan telah memperoleh "Ethical Clearance" dari komite etik penelitian Fakultas Kedokteran Universitas Sriwijaya Palembang. 


\section{HASIL PENELITIAN}

Tabel. 1

Pengaruh Paparan Radiasi Gelombang Elektromagnetik Wi-Fi4G terhadap Berat Epididimis Kiri dan Kanan

\begin{tabular}{|c|c|c|c|c|}
\hline \multirow[t]{2}{*}{ Paparan Radiasi Wi-Fi 4G } & $\mathrm{n}$ & Berat Epididimis kiri & Berat Epididimis Kanan & \multirow[t]{2}{*}{$p$ value } \\
\hline & \multicolumn{3}{|c|}{ Rata-rata \pm SD } & \\
\hline Kontrol & 7 & $0,510 \pm 0,056 \mathrm{c}$ & $0,522 \pm 0,056 \mathrm{c}$ & \\
\hline $8 \mathrm{Jam}$ & 7 & $0,438 \pm 0,016 b$ & $0,448 \pm 0,015 b$ & 0,000 \\
\hline $16 \mathrm{Jam}$ & 7 & $0,414 \pm 0,038 b$ & $0,420 \pm 0,037 \mathrm{~b}$ & \\
\hline $24 \mathrm{Jam}$ & 7 & $0,361 \pm 0,046 \mathrm{a}$ & $0,371 \pm 0,048 \mathrm{a}$ & \\
\hline
\end{tabular}

Tabel 1 menunjukkan bahwa hasil uji statistik dengan menggunakan uji one way anova didapatkan nilai $\mathrm{p}=0,000$ dengan nilai alpha $0,05(\mathrm{p}<\alpha)$, hal ini menunjukkan bahwa terdapat perbedaan rerata berat epididimis kanan antar kelompok paparan radiasi gelombang elektromagnetik wi-fi 4G.

Pada tabel 1 didapatkan hasil uji anova $p<0,000$ sehingga dapat dianalisis dari hasil uji lanjut dengan menggunakan duncan menunjukan berat epididimis kanan pada paparan radiasi gelombang elektromagnetik wi-fi $4 \mathrm{G}$ kelompok kontrol berbeda nyata dengan kelompok perlakuan 8 jam, 16 jam dan 24 jam, paparan radiasi gelombang elektromagnetik wi-fi $4 \mathrm{G}$ selama 8 jam dan 16 jam sudah mempengaruhi berat epididimiskanan, namun paparan radiasi selama 24 jam lebih mempengaruhi berat epididimis kanan.

Tabel. 2

Pengaruh Paparan Radiasi Gelombang Elektromagnetik Wi-Fi terhadap Morfologi

\begin{tabular}{llll}
\hline Paparan Radiasi Wi-Fi 4G & N & $\begin{array}{l}\text { Morfologi abnormal (\%) } \\
\text { Rata-rata } \pm \text { SD }\end{array}$ & p value \\
\hline Kontrol & 7 & $49,64 \pm 4,07$ a & \\
8 Jam & 7 & $51,00 \pm 5,14$ a & 0,000 \\
16 Jam & 7 & $53,42 \pm 3,70$ a & \\
24 Jam & 7 & $63,85 \pm 7,83 \quad$ b & \\
\hline
\end{tabular}

Keterangan :One Way Anova $p<0,05$. Angka-angka yang diikuti huruf yang berbeda menunjukan ada perbedaan yang bermakna nyata pada uji lanjut Duncan $(p<0,05)$

Tabel 2 menunjukkan bahwa hasil uji statistik dengan menggunakan uji one way anova didapatkan nilai $\mathrm{p}=0,000$ dengan nilai alpha $0,05(\mathrm{p}<\alpha)$, hal ini menunjukkan bahwa terdapat perbedaan rerata morfologi sperma antar kelompok paparan radiasi gelombang elektromagnetik wi-fi $4 \mathrm{G}$.

Pada tabel 2 didapatkan hasil uji anova $p<0,000$ sehingga dapat dianalisis dari hasil uji lanjut dengan menggunakan duncan menunjukan morfologi pada paparan radiasi gelombang elektromagnetik wi-fi $4 \mathrm{G}$ paparan radiasi gelombang elektromagnetik wi-fi $4 G$ selama 24 jam berbeda nyata dengan paparan radiasi 8 jam, 18 jam dan kontrol. Artinya paparan radiasi selama 24 jam lebih mempengaruhi jumlah morfologi sperma. 


\section{PEMBAHASAN}

\section{Pengaruh Paparan Radiasi Gelombang Elektromagnetik Wi-Fi $4 G$ terhadap Berat Epididimis}

Hasil uji one way anova diperoleh $p<0,05$ pemberian paparan radiasi gelombang elektromagnetik Wi-Fi4G memiliki pengaruh menurunkan berat epididimis pada tikus putih jantan, hal ini dapat dilihat dari berat epididimis kiri dan kanan menurun pada kelompok perlakuan 8,16, dan 24 jam di banding kontrol, hasil penelitian ini sesuai dengan Dasdag.S. et al, (2015) yang melakukan pengamatan yang dilakukan pada tikus jantan yang dipapar oleh gelombang elektromagnetik mendapatkan hasil berat epididimis menurun pada tikus yang mendapat paparan, penurunan berat epididimis ini diduga disebabkan karena terjadinya gangguan terhadap perkembangan maupun fungsi epididimis. Vas deferens merupakan suatu saluran yang menghubungkanepididimis dan uretra. Letak vas deferens dimulai dari ujung kauda epididimis yang ada dalam kantung skrotum, lalu naik ke bagian atas lipat paha, pada bagian ujungnya, vas deferens dikelilingi oleh suatu pembesaran kelenjar-kelenjar yang disebut ampula.Sebelum masuk ke uretra, vas deferens ini bergabung terlebih dahulu dengan saluran ekskresi vesika seminalis membentuk duktus ejakulatoris. Pada saat ejakulasi sperma dari epididimis diangkut melalui vas deferens dengan 20 suatu seri kontraksi yang dikontrol oleh syaraf vas deferens akan melalui kanalis inguinalis masuk ke dalam rongga tubuh dan akhirnya menuju uretra penis. Uretra penis dilalui oleh sperma dan urin. Sperma akan melalui vas deferens oleh kontraksi peristaltik dindingnya dan membentuk sekitar 20 persen massa testis dewasa (Guyton, Hall, 2008).

Pembentukan spermatogenesis selain dipengaruhi oleh testosteron, LH, juga dipengaruhi oleh hormon FSH. FSH berfungsi untuk menggertak testis dan memacu proses spermatogenesis, yaitu pembentukan spermatogonia menjadi spermatid. Selain itu FSH juga merangsang sel sertoli dalam pembentukan protein pengikat androgen $(\mathrm{ABP})$, yang berperan dalam pengangkutan testosteron ke dalam tubulus seminiferus dan epididymis, mekanisme ini penting untuk mencapai kadar testosteron yang dibutuhkan untuk terjadinya spermatogenesis. Selain membentuk protein pengikat androgen (ABP), sel sertoli juga membentuk inhibin. Inhibin adalah suatu hormon nonsteroid yang mempunyai mekanisme umpan balik untuk menghambat produksi FSH yang berlebihan. FSH sangat dibutuhkan pada saat aktifitas proliferasi dari spermatogonium, sehingga jika FSH terhambat maka suplai glukosa dan sintesis protein juga terhambat. Selain itu FSH juga berperan penting dalam menunjang tahap pematangan maupun reduksi meiosis dari spermatosit primer. Jika FSH turun maka akan menyebabkan perubahan sitoskeletal sel sertoli sehingga menyebabkan suplai laktat dan piruvat pada spermatosit primer dan spermatid juga akan menurun (Satriyasa, 2008).

Epididimis merupakan suatu struktur berbentuk koma yang menahan batas posterolateral testis. Epididimis dibentuk oleh saluran yang berlekuk-lekuk secara tidak teratur yang disebut duktus epididimis. Duktus epididimis memiliki panjang sekitar 600 $\mathrm{cm}$. Duktus ini berawal pada puncak testis yang merupakan kepala epididimis. Setelah melewati jalan yang berliku-liku, duktus ini berakhir pada ekor epididimis yang kemudian menjadi vas deferens (Guyton, Hall, 2008).

Epididimis terletak pada bagian dorsal lateral testis, merupakan suatu struktur memanjang dari bagian atas sampai bagian bawah testis. Organ ini terdiri dari bagian kaput, korpus dan kauda epididimis Epitel epididimis memiliki dua fungsi. Pertama, mensekresikan plasma epididimis yang bersifat kompleks tempat sperma tersuspensikan 
dan mengalami pematangan. Kedua, mengabsorbsi kembali cairan testikuler yang mengangkut sperma dari tubulus semineferus dan sperma yang sudah rusak.

Pada penelitian pada manusia Paparan laptop terhubung internet nirkabel Wi-Fi menunjukan penurunan motilitas sperma dan peningkatan fragmentasi DNA sperma pada manusia (Canrado et al, 2012).

Penelitian sampel tikus didapatkan bahwa paparan radiasi gelombang elektromagnetik pada tikus dengan paparan 7 jam perhari selama 60 hari memiliki pengaruh yang signifikan dengan penurunan motilitas spermatozoa, ini terjadi karena adanya radikal bebas, radikal bebas adalah molekul yang mempunyai atom dengan electron yang tidak berpasangan radikal bebas yang tidak stabil dan mempunyai reaktivitas yang tinggi dapat merusak seluruh tipe mitokondria seluler termasuk karbonhidrat, protein lipit, dan asam nukleat, reactive oxygen spesies (ROS) yang dapat menyebabkan stres oksidatif dan peroksidasi lipid pada membran sel, sehingga permeabilitas membran sel meningkat (Shokri et al, 2014).

Hal ini kemungkinan disebabkan juga sama karena kelebihan reactive oksigens spesies (ROS) dapat merusak sperma dan ROS telah dikeahui sebagai salah satu penyebab infertilitas. Radikal bebas menyebabkan mutasi DNA dan sitotoksis. Sitotossis dapat menyebabkan kematian dan penurunan jumlah se dalam jaringan yang akan mengakibatkan apoptosis disebabkan tekanan oksidatif radiasi elektromagnetik adalah salah satu toxicants lingkungan yang mampu mengorbankan kesuburan pria dengan menginduksi keadaan stres oksidatif dalam testis.Akibatnya ada kebutuhan mendesak untuk mengidentifikasi antioksidan yang dapat melengkapi srategi antioksida jaringan sendiri untuk menyelamatkan testis dari konsekuensi dari serangan ROS. Dalam vitro studi oleh avendano et al di fokuskan pada efek radiasi wi-fi pada pengurangan motilitas dan DNA fragmentasi spermatozoa manusia. Hal ini di yakini bahwa paparan EMR dapat meningkatkan produksi spesies Oksigeal Reaktif (ROS) peningkatan tingkat peroksidasi lipid selain penurunan enzim antioksidan, dan mempercepar apoptosis yang pada akhirnya mempengaruhi kualitas sperma (Halil. 1 et al, 2012).

Sedangkan pada thermal panas sebagai bentuk stres fisik seperti halnya dingin, radiasi, getaran, bising dan psikologis mengaktifkan respon senteral dan perifer pada system endokrin syaraf otonom sebagai bentuk reaksi adaptasi. Aktivasi sistem endokrin yaitu sumbu Hipotalamus-Hipofise-Adrenal (HHA) melibatkan pengeluaran neuro hormone $\mathrm{CRH}$ (corticotropin releasing hormone). Peningkatan $\mathrm{CRH}$ yang menimbulkan penurunan GnRH menyebabkan penurunan produksi FSH (Folikel Stimulating Hormon) dan LH oleh adenohipofisis maka terjadi gangguan pada sumbu HHT, berupa penurunan LH, FSH, testosterone jelas mengganggu kualitas spermatozoa. Disamping itu peningkatan suhu akan mengakibatkan gangguan fungsi epididimis dalam pematangan spermatozoa termasuk dalam memberikan pasokan bahan makanan terutama glukosa sebagai substrat untuk metabolisme spermatozoa. Aktivitas maksimumuntuk sebagian besar enzim manusia berlangsung sekitar suhu $37^{\circ} \mathrm{C}$ karena pada suhu yang lebih tinggi terjadi denaturasi (hilangnya struktur skunder dan tertier) (Marks n'Smith, 1996 dalam Ermiza 2012). Baik denaturasi enzim spermatozoa maupun gangguan pasokan glukosa sehingga menyebabkan terjadinya penurunan kualitas spermatozoa termasuk viabilitas spermatozoa dan akan terbentuknya spermatozoa yang abnormal (Banks, 2005 dalam Ermiza, 2012).

Kualitas sperma merupakan kondisiatau keadaan yang dimiliki oleh spermatozoa. Sperma yang berkualitas adalah sperma yang memiliki kondisi normal serta mampu 
untuk membuahi sel telur atau ovum, dengan adanya pemanasan thermal mengakibatkan kualitas sperma terganggu (ermiza, 2012). Karena terpapar gelombang listrik terus menerus akan meningkatkan suhu maka menyebabkan terjadinya perubahan di dalam duktus epididimis yaitu degenerasi epitel epididimis dan jaringan menyebabkan berat organ di epidedemis menurun (Dasdag.S et al, 2015).

\section{Pengaruh Paparan Radiasi Gelombang Elektromagnetik Wi-Fi 4G terhadap Morfologi Sperma}

Hasil uji one way anova diperoleh $p<0,05$ paparan radiasi gelombang elektromagnetik 4G memiliki pengaruh menurunkan motilitas sperma pada tikus putih jantan, hal ini dapat dilihat dari persentase motilitas sperma menurun pada kelompok perlakuan 8,16, dan 24 jam paparan di banding kelompok kontrol.

Hal ini sejalan dengan penelitian (Shokri et al, 2014) dalam penelitian deskriptifnya menyatakan bahwa paparan radiasi gelombang elektromagnetik pada tikus dengan paparan 7 jam perhari selama 60 hari memiliki pengaruh yang signifikan dengan penurunan motilitas spermatozoa. Ini terjadi karena adanya radikal bebas, radikal bebas adalah molekul yang mempunyai atom dengan electron yang tidak berpasangan radikal bebas yang tidak stabil dan mempunyai reaktivitas yang tinggi dapat merusak seluruh tipe mitokondria seluler termasuk karbonhidrat, protein lipit, dan asam nukleat.

Molekul glikoprotein yang berada dipermukaan spermatozoa akan dikenali oleh sistem imun dan merupakan tanda bahwa sel tersebut (spermatozoa). Harus dilenyapkan oleh tubuh. Ketika spermatozoa meninggalkan testis, perlindungan terhadap sistem imun menjadi berkurang sehingga banyak spermatozoa yang rusak atau mati. Selain sumber ROS yang berasal dari faktor gelombang elektromagnetik. Pada kadar yang tinggi ROS berpotensi menimbulkan efek toksik, sehingga dapat berpengaruh pada kualitas dan fungsi spermatozoa abnormalisasi morfologi spermatozoa dapat dikelompokkan dalam tiga kategori, yaitu primer (mempunyai hubungan erat dengan kepala spermatozoa dan akrosom), sekunder (keberadaan droplet pada bagian tengah ekor) dan tersier (kerusakan pada ekor) (Al-Haija, Rania Wasef, 2011).

Jenis morfologi sperma menurut (WHO, 2010) adalah: Sperma normal mempunyai panjang dan lebar dengan batas teratur. Bagian kepala berkait berbentuk bulan sabit dan bagian ekor panjang tidak mengulung.

Sperma abnormal, meliputi sperma makro: mempunyai ukuran kepala lebih besar dari pada normal, sperma mikro: mempunyai ukuran kepala yang lebih kecil dari pada normal, sperma double hand: mempunyai kepala dua dengan bentuk dan ukuran bervariasi, sperma amorf: mempunyai bentuk kepala yang aneh sehingga tidak dapat di golongkan kedalam sati kategori.

Pada bagia leher dan tengah sperm: sperma defek: sperma yang bagian tengahnya membelit atau patah, sperma loose head: sperma tanpa kepala. Sementara pada bagian ekor: sperma koil: mempunyai kelainan pada bagian ekor berupa bagia ekor membelit, sperma double tail: sperma dengan ekor ganda.

Ghanbari (2013) dalam penelitiannya pada 28 tikus putih jantan galur Wistar yang dipapar dengan gelombang elektromagnetik handphone simulasi dengan durasi 8 jam per hari dalam waktu 3 minggu, juga menghasilkan gambaran berupa penurunan motilitas yang bermakna apabila dibandingkan dengan kelompok kontrol yang tidak terpapar. Qin (2014) juga melakukan penelitian untuk mengetahui pengaruh medan elektromagnetik dengan frekuensi $1800 \mathrm{MHz}$ terhadap efek sirkardian dari fungsi reproduksi. Tikus dipapar dengan durasi 2 jam setiap hari dalam waktu 32 hari dan 
didapatkan hasil berupa penurunan motilitas spermatozoa yang bermakna pada tikus putih jantan yang terpapar.

Gelombang elektromagnetik menghasilkan Reactive Oksigens Spesies (ROS) yang dapat menyebabkan stres oksidatif dan peroksidasi lipid pada membran sel sehingga permeabilitas membran sel meningkat. Permeabilitas membran yang meningkat mengakibatkan homeostasis $\mathrm{Ca} 2+$ sel terganggu, sehingga terjadi deplesi $\mathrm{Ca} 2+$ bersama dengan makromolekul lain seperti ATP dari dalam sel yang keduanya diperlukan untuk motilitas spermatozoa. Ion $\mathrm{Ca} 2+$ juga digunakan untuk mengaktivasi protein kinase $\mathrm{C}(\mathrm{PKC})$ yang terletak di flagelum sperma dan berfungsi untuk mengatur motilitas spermatozoa. Sehingga dengan homeostasis Ca2+ yang terganggu, PKC juga tidak dapat berfungsi secara optimal dan menghasilkan spermatozoa dengan motilitas yang tidak baik (Hamada et al, 2011).

Sesuai dengan penelitian Dasdag.S et al, (2015) yang melakukan pengamatan yang dilakukan terhadap testis tikus jantan yang dipapar oleh gelombang elektromagnetik mendapatkan hasil cacat kepala meningkat pada waktu pemeriksaan morfologi sperma, hal ini kemungkinan dari timbulnya karena proses thermal dan no thermal. Pada proses non thermal kemungkinan karena radikal bebas dalam tubuh telah diimbangi dengan mekanisme endogen dengan memproduksi zat yang mempunyai pengaruh sebagai anti radikal bebas yang disebut antioksidan, akan tetapi pada saat level ROS meningkat ketika terpapar radiasi gelombang elektromagnetik melebihi dari sistem pertahanan antioksidan tubuh terjadi stress oksidatif, stress oksidatif merupakan kondisi dimana terjadi peningkatan ROS yang akan menyebabkan kerusakan sel, jaringan atau organ Reaksi ROS terhadap lipid tidak jenuh membran sel dan plasma lipoprotein menyebabkan pembentukan lipid peroksida (malondialdehyde) yang secara kimia dapat memodifikasi protein dan asam basa asam nukleat selain itu ROS secara kimiawi juga dapat memodifikasi langsung asam amino dalam protein (Bender DA, 2009 dalam Amarudin, 2012).

Reaksi ROS terhadap lipid tidak jenuh membran sel dan plasma lipoproteini menyebabkan pembentukan lipid peroksida (malondialdehyde) yang secara kimia dapat memodifikasi protein dan asam basa asam nukleat selain itu ROS secara kimiawi juga dapat memodifikasi langsung asam amino dalam protein. ROS dapat mengakibatkan terjadi peroksidasi lipit dapat menimbulkan kegagalan dalam spermatozoa karena membran plasma yang rusak menyebabkan meningktakan membran sel dalam pada kepala spermatozoa sehingga banyak senyawa-senyawa yang tidak di inginkan mudah masuk dalam sel (Dasdag.S et al, 2015).

ROS juga dapat menurunkan frekuensi gerakan ekor spermatozoa karena radikal bebas menyebabkan produksi ATP mitokondria rendah. Mitokondria merupakan tempat proses perombakan atau katabolisme untuk menghasilkan energi bagi pergerakan ekor Spermatozoa Reactive Oksigens Spesies (ROS) adalah molekul yang tidak berpasangan dan oleh karena itu sangat tidak stabil dan sangat reaktif, ROS hanya dapat bertahan dalam hitungan millisecond sebelum bereaksi dengan molekul lain untuk menstabilkan diri kerusakan jaringan akibat serangan ROS disebut stress oksidatif (Ladiges W, 2010).

Reactive Oxygen Spesies (ROS) dapat mengakibatkan terjadi peroksidasi lipid dapat menimbulkan kegagalan dalam spermatozoa karena membran plasma yang rusak, menyebabkan meningktakan membran sel sehingga terjadi kelainan pada kepala spermatozoa, beberapa hasil penelitian yang terkait antara lain. Dasdag.S et al, (2015) yang melakukan pengamatan yang dilakukan terhadap testis tikus jantan yang dipapar oleh gelombang elektromagnetik mendapatkan hasil cacat kepala meningkat pada waktu pemeriksaan morfologi sperma, penelitian terdapat penurunan viabilitas sperma yang 
terpapapar radiasi gelombang elektromagnetik pada tikus berumur 12 minggu, terpapar selama 2 jam perhari selama 30 hari, kemungkinan ini disebabkan stress oksidatif didalam sel dan jaringan (Chaturvedi CM,et al, 2014).

Reaksi ROS terhadap lipid tidak jenuh membran sel dan plasma lipoproteini menyebabkan pembentukan lipid peroksida (malondialdehyde) yang secara kimia dapat memodifikasi protein dan asam basa asam nukleat selain itu ROS secara kimiawi juga dapat memodifikasi langsung asam amino dalam protein. ROS dapat mengakibatkan terjadi peroksidasi lipit dapat menimbulkan kegagalan dalam spermatozoa karena membran plasma yang rusak menyebabkan meningktakan membran sel dalam pada kepala spermatozoa sehingga banyak senyawa-senyawa yang tidak di inginkan mudah masuk dalam sel (Dasdag.S et al, 2015).

ROS juga dapat menurunkan frekuensi gerakan ekor spermatozoa karena radikal bebas menyebabkan produksi ATP mitokondria rendah. Mitokondria merupakan tempat proses perombakan atau katabolisme untuk menghasilkan energi bagi pergerakan ekor spermatozoa (Amiruddin, 2012).

Hal ini sesuai penelitian Halil. L et al, (2012) yang mengatakan tikus yang terkena paparan sumber gelombang radio frekuensi wi-fi selama 24 jam sehari selama 20 minggu menunjukan kerusakan DNA dan ditemukannya penurunan kadar katalase dan peroksidase glutathione. ROS adalah molekul yang tidak berpasangan dan oleh karena itu sangat tidak stabil dan sangat reaktif, ROS hanya dapat bertahan dalam hitungan millisecond sebelum bereaksi dengan molekul lain untuk menstabilkan diri kerusakan jaringan akibat serangan ROS disebut stress oksidatif (Ladiges W. et al, 2010).

Pada proses thermal terjadinya sebab radiasi pada intensitas tinggi berbahaya karena kemampuannya meningkatkan temperatur tubuh secara drastis dapat merusak jaringan. Prinsip ini seperti microwave yang biasa kita gunakan untuk memanaskan makanan, kerusakan jaringan biasanya terjadi karena tubuh tidak dapat menghilangkan panas berlebihan yang masuk ke dalam tubuh, seperti penelitian Ermiza (2012) mengatakan pemaparan suhu $40^{\circ} \mathrm{C}$ berpengaruh terhadap morfologi spermatozoa mencitjantan, paparan suhu $40^{\circ} \mathrm{C}$ menyebabkan terjadinya kerusakan enzim karena pada suhu yang lebih tinggi terjadi denatures (hilangnya struktur sekunder dan tertier) (Marks, Smith, 1996; Ermiza, 2012). 


\section{SIMPULAN}

Berdasarkan hasil penelitian mengenai pengaruh paparan radiasi gelombang elektromagnetik wi-fi $4 \mathrm{G}$ terhadap berat epididemis dan morfologi sperma pada tikus jantan wistar (rattus norvegicus) selama 48 hari.

Paparan radiasi gelombang elektromagnetik wi-fi 4G berpengaruh dalam menurunkan berat epididimis, terutama pada paparan 24 jam. Paparan radiasi gelombang elektromagnetik wi-fi $4 \mathrm{G}$ berpengaruh dalam menurunkan morfologi sperma yang paling besar pada paparan 24 .

\section{SARAN}

1. Bagi masyarakat agar mengurangi aktivitas penggunaan wi-fi, dan mati kan sinyal wi-fi jika tidak digunakan, hal ini untuk mencegah radiasi wi-fi masuk ke tubuh kita dan yang sering melakukan aktivitas berlebih disarankan untuk mengkonsumsi antioksidan yang dapat mencegah terjadinya stress oksidatif.

2. Bagi peneliti selanjutnya perlu dilakukan penelitian pengaruh gelombang elektromagnetik dengan parameter kualitas spermatozoa yang lain dan suhu, paparan yang lama.serta menentukan indikator stress oksidatif karna paparan gelombang elektromagnetik wi-fi $4 \mathrm{G}$ untuk pemberian antioksidan. 


\section{DAFTAR PUSTAKA}

Al-Haija, R. W. (2011). Main Causes of Infertility Among Men Treated at Razan Centers in West Bank: Retrospective Study. Tesis, An-Najah National University Faculty Graduate Studies

Amiruddin. (2012). Pengaruh Merokok terhadap Kualitas Sperma pada Pria dengan Masalah Infertilitas Studi Kasus Kontrol di Jakarta Tahun 2012. Tesis. Universitas Indonesia

Ashafahani, E. D., Wiratmi, N. I., \& Sukmaningsih, A. A. S. A. (2010). Motilitas dan Viabilitas Spermatozoa Mancit (Mus Musculus) Setelah Pemberian Ekstrak Temu Putih (Curnuma Zedoaria) Roscoe. Jurnal Biologi, 14(1), 20-24

Chatur, V. C. M. (2014). 2,45 GHz Microwave Irradiation Adversely Affects Reproductive Function in Male Mouse, Mus Musculus by in Cluding Oxidative and Nitrosative Stsress. Free Radical Researc ch, 48(5), 511-525

Conrado. A. (2012). Use of Laptop Computers Connected to Internet Through Wi-Fi Decreases Human Sperm Motility and Increases Sperm DNA Fragmentation. Argentina. Journal Andrology, 97(1), 39-41

Dahlan \& Sopiyudin. (2011). Statistik untuk Kedokteran dan Kesehatan Edisi 5. Jakarta: Salemba Medika

Dasdag, S. (2015). Effect of Long Term Exposure of 2,45 GHz Radio Frequency Radiation Emitted from Wi-Fi Equipment on Testes Functions. Turkey: Jurnal Biology and Medicine,34(1), 37-42

Ermiza. (2012). Pengaruh Paparan Suhu terhadap Kualitas Spermatozoa Mencit Jantan (Mus Musculus) Strain Jepang. Jurnal Sainttis, 1(2), 1-28

Foster, K. R. (2013). Wi-Fi and Healty: REVIEW of Current Status of Research. Healty Physiologi, 2, 561-572

Ghanbari, M., Mortazavi, S. B., Khavanin, A., Khazaei, M. (2013). The Effects of Cell Phone Waves (900 MHz-GSM Band) on Sperm Parameters and Total Antioxidants Capacity in Rats. Int Jour Fert and Ste, 7(1), 21-8

Gilbert, A \& Oni. (2011). Effects of Radio Frequency Radiation From Wi-Fi Devices on Human Ejaculated Semen (2011). Journal IJRRAR,9(2), 292-294

Guyton, A. C \& Hall, J. E. (2008). Buku Ajar Biologi Kedokteran Edisi II

Halil, 1. (2012). Immunohistopathologic Demonstration of Deleterious Effects on Growing Rat Testes of Radiofrequency Waves Emitted from Conventional Wi-Fi Devices. Jurnal Pediatric Urology, 9(2), 223-229

Hamada, A. J., Singh, A., Agarwal, A. (2011). Cell Phones and Their Impact on Male Fertility: Fact or Fiction. The Open Reproductive Science Journal, (5), 125-37

Kosar, P. A. (2014). Protective Effect of Melatonin Against Okidative Injury in Rat Testis Incuced by Wireless (2.45 Ghz) Devices. Jurnal Andrologi 2014

Kumar, S. (2013). Influence of Elektromagnetik FielDS on Reproductive Sytem of Male Rats: Internasional Jurnal Radiat Biologi

Ladiges, W. (2010). A Mitochondrial View of Aging Reactive Oxygen Species and Metastatic Cancer. Aging Cell, 9, 462-465

Permadi. (2008). Mengatasi Infertilitas. Bandung: PT Grafindo

Purwantara., Ariffiantini \& Sukmawati, E. (2014). Daya Tahan Spermatozoa terhadap Proses Pembekuan pada Berbagai Jenis Sap Pejantan Unggul. JITV, 9(3)

Qin F, Zhang J, Cao H, Guo W, Chen L, Shen O. (2014). Circardian Alterations of Reproductive Functional Markers in Male Rats Ecposed to $1800 \mathrm{MHz}$ Radiofrequency Field. Chronobiol Int, 31(1), 123-33 
Roupa, Z., Polikandrioti, M., Sotiropoulou, P., Faros, E., Koulouri, A., Wozniak, G. (2009). Causes of Infertility in Women at Reproductive Age. 3(2), 80-7

Samal, S., Dhadwe, K \& Gupta, U. (2012). Epidemiologigical Study of Male Infertility. Indian Medical Gazette

Saraswati, A. (2015). Artikel Review Infertility. Majority, 4(5)

Satriyasa, B. K. (2007). Fraksi Heksan dan Fraksi Methanol Ekstra Biji Papaya Muda Menghambat Spermatogonia Mencit (Mus Musculus) Jantan. Jurnal Vetenier Denpasar Bali

Shokri, S. (2014). Effects of Wi-Fi (2.45 GHz) Exposure on Apoptosis, Sperm Parameters and Testicular Histomorphometry in Rats: A Time Course Study: Cell Journal, 17(2), 322-331

Soleimani. (2015). Effects of Microwave Electromagnetic Radiations Emitted from Common Wi-Fi Routers on Rats Sperm Count and Motility. Internasional Jo urnal of Radiation Research, 13(4), 364-368

Suarni, N. M. R \& Ermayati, N. G. A. M. (2010). Kualitas Sperma Mancit (Mus Musculus L) Setelah Perlakuan Infus Kayu Amargo (Quassia amara Linn) dan Pemulihannya. Jurnal Biologi, 14, 45-49

Suwandi, T. J. (2012). Pemberian Ekstrak Kelopak Bunga Rosella Menurunkan Melondialdehid pada Tikus Rattus Norvegicus yang di Beri Minyak Jantan: Tesis Universitas Udayana

Swardik, A. (2009). Pengaruh Radiasi Gelombang Elektromagnetik terhadap Kesehatan Manusia. Jurnal Elektro, 8(1), 106-109

WHO. (2010). Laboratory Manual for the Examination and Processing of Human Semen. Fifth Edition Cambriage University Press Cambridge 